\title{
Effect of Deposition Temperature on Surface Morphology and Electrical Properties of Fluorine Doped Tin Oxide (FTO) Thin Film by Spray Pyrolysis Technique
}

\author{
NOOR SAKINAH Khalid ${ }^{1, a^{*}}$, SOO REN How ${ }^{2, b^{*}}$, JAIS Lias $^{2, \mathrm{c}}$, \\ MOHD KHAIRUL Ahmad ${ }^{3, d}$ \\ ${ }^{1}$ Microeletronics \& Nanotechnology - Shamsuddin Research Centre (MiNT-SRC), Department \\ of Electronics, Faculty of Electrical \& Electronic Engineering, Universiti Tun Hussein Onn Malaysia \\ (UTHM) JOHOR, 86400 Parit Raja, Batu Pahat Johor, Malaysia \\ ${ }^{2}$ Faculty of Electrical and Electronic Engineering, Universiti Tun Hussein Onn Malaysia (UTHM) \\ JOHOR, 86400 Parit Raja, Batu Pahat Johor, Malaysia \\ ${ }^{3}$ Solar Device Research Laboratory, Microeletronics \& Nanotechnology - Shamsuddin Research \\ Centre (MiNT-SRC), Department of Electronics, Faculty of Electrical \& Electronic Engineering, \\ Universiti Tun Hussein Onn Malaysia (UTHM) JOHOR, 86400 \\ Parit Raja, Batu Pahat Johor, Malaysia

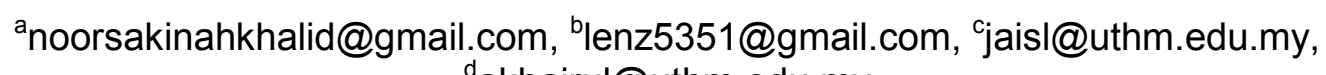 \\ dakhairul@uthm.edu.my
}

Keywords: FTO, thin film, spray pyrolysis deposition, surface morphology.

\begin{abstract}
Fluorine doped tin oxide, $\mathrm{SnO}_{2}: \mathrm{F}$ (FTO) thin films were prepared at different deposition temperatures using the spray pyrolysis deposition (SPD) technique. The deposition temperature were ranging from $250^{\circ} \mathrm{C}$ to $450^{\circ} \mathrm{C}$ and the precursor used was $0.5 \mathrm{M}$ of $\mathrm{SnCl}_{4} .5 \mathrm{H}_{2} \mathrm{O}$ and $1.527 \mathrm{M}$ of $\mathrm{NH}_{4} \mathrm{~F}$ completely dissolved in distilled water. It was observed that the conductivity of the FTO thin film increased with increasing of deposition temperature. At $450^{\circ} \mathrm{C}$, it was shown the conductivity became smaller. Surface morphologies of FTO thin films at different deposition temperature had shown that the growth of crystallite particles and its distributions were totally affected by the deposition temperature. The transmittance of FTO thin films was over $80 \%$ within the wavelength from $300 \mathrm{~nm}-800 \mathrm{~nm}$. Thus, the best deposition temperature to be used is around $350^{\circ} \mathrm{C}$ to $400^{\circ} \mathrm{C}$ for depositing the FTO film.
\end{abstract}

\section{Introduction}

Tin (II) oxide $\left(\mathrm{SnO}_{2}\right)$ film is a metal oxide semiconductor which has been widely used in optoelectronic devices. It has a crystalline solid with a tetragonal crystal lattice [1-2]. $\mathrm{SnO}_{2}$ has found in solar cells, flat panel displays, photovoltaic devices, gas sensors and heat reflecting mirrors devices due to its band gap energy of about $2.8 \mathrm{eV}-4.2 \mathrm{eV}$ [3-4]. It also allows visible and IR reflection radiation besides its adherence to the substrates. An important property of $\mathrm{SnO}_{2}$ is that it is chemically stable in atmospheric ambient among the other metal oxides semiconductor such as $\mathrm{In}_{2} \mathrm{O}_{3}, \mathrm{Cd}_{2} \mathrm{SnO}_{4}, \mathrm{CdO}$ and $\mathrm{ZnO}[4]$.

In solar cells technologies, an important application of thin film technology has been for the development of transparent conducting oxide (TCO). However, the pure $\mathrm{SnO}_{2}$ which possesses either an insulator or intrinsic semiconductor properties definitely would give higher resistivity values and it also has a high optical transparency in the visible range. In order to use it as a conducting layer, the resistivity of $\mathrm{SnO}_{2}$ has to be reduced [4]. The electrical conductivity could be improved by appropriate doping. Therefore, fluorine have been used as dopants for $\mathrm{SnO}_{2}$ thin film to reach a greater metal-like conductivity and carrier mobility instead of other dopants for it to contribute to higher optical transmittance [9]. 
In the market nowadays FTO is quite expensive; by doing this research we suggest that the production cost will be cheaper. Spray pyrolysis method had been chosen because it is low cost and the uniformity can be achieved [9-10]. So, in this paper, the deposition temperature effect on FTO will be study for surface analysis, optical and electrical properties.

\section{Experimental/Methodology}

Preparation of FTO thin film using SPD technique. FTO solution was prepared by mixing tin (IV) chloride penta-hydrate $\left(\mathrm{SnCl}_{4} .5 \mathrm{H}_{2} \mathrm{O}\right)$ and ammonium fluoride $\left(\mathrm{NH}_{4} \mathrm{~F}\right)$ in distilled water. $0.5 \mathrm{M}$ of $\mathrm{SnCl}_{4} .5 \mathrm{H}_{2} \mathrm{O}$ and $1.527 \mathrm{M}$ of $\mathrm{NH}_{4} \mathrm{~F}$ was used as FTO solution. The solution was stirred until solution was clear and stable. Glass substrates were prepared for the deposition. Spray pyrolysis involved the spraying the solution onto a substrate on the hot plate. The deposition temperature of hot plate was varied in the range from $250^{\circ} \mathrm{C}$ to $450^{\circ} \mathrm{C}$.

Characterization of FTO Thin Film. The surface morphology of the FTO thin films were examined by field-electron scanning electron microscopy (FESEM). The measurement of electrical properties of FTO was determined using two point probe. The thickness of FTO thin films were measured by surface profiler. UV-Vis spectrometer was used to determine the transmittance of FTO thin film at room temperature within the wavelength range of $300 \mathrm{~nm}$ to $800 \mathrm{~nm}$.

\section{Results and Discussions}

Surface morphology analysis. The surface morphology of FTO thin film from FESEM was shown as in Figure 1. The figures indicate that the FTO crystallites was well formed and densely packed with increasing of deposition temperature. For the temperature of $250^{\circ} \mathrm{C}$, the arangement of crystallite particles was less dense and the FTO particles just started to attach on the substarate. Comparison of the images of FTO film for $250^{\circ} \mathrm{C}$ and of $300^{\circ} \mathrm{C}$, it shows that the one with higher temperature has greater density of crytallite particles. At $350^{\circ} \mathrm{C}$, the density of the crystallite particles becomes higher and almost dense packed compared to the temperature of $300^{\circ} \mathrm{C}$. At $400^{\circ} \mathrm{C}$, the area was fully deposited with the crystallite particles and has greater density growth. However at $450^{\circ} \mathrm{C}$, the number of crystallite particles started to decrease and it become less densely packed. This phenomena happened because some of the crystallite particles vapourised due to surrounding pressure of hot plate.

This could be explained by paper reported by Demet et al. [5] stated that at low temperature e.g. $250^{\circ} \mathrm{C}$, the heat may not enough to decomposed the sprayed droplets of $\mathrm{Sn}^{2+}$ and $\mathrm{F}^{-}$ions from the solutions, thus results in less dense arrangement. At deposition temperature of $400^{\circ} \mathrm{C}$, optimum decomposition occour and resulting in dense packed arrangment. However, when the temperature exceeds $400^{\circ} \mathrm{C}$, the density is decrease because re-evaporation of film substance after deposition process [5]. 


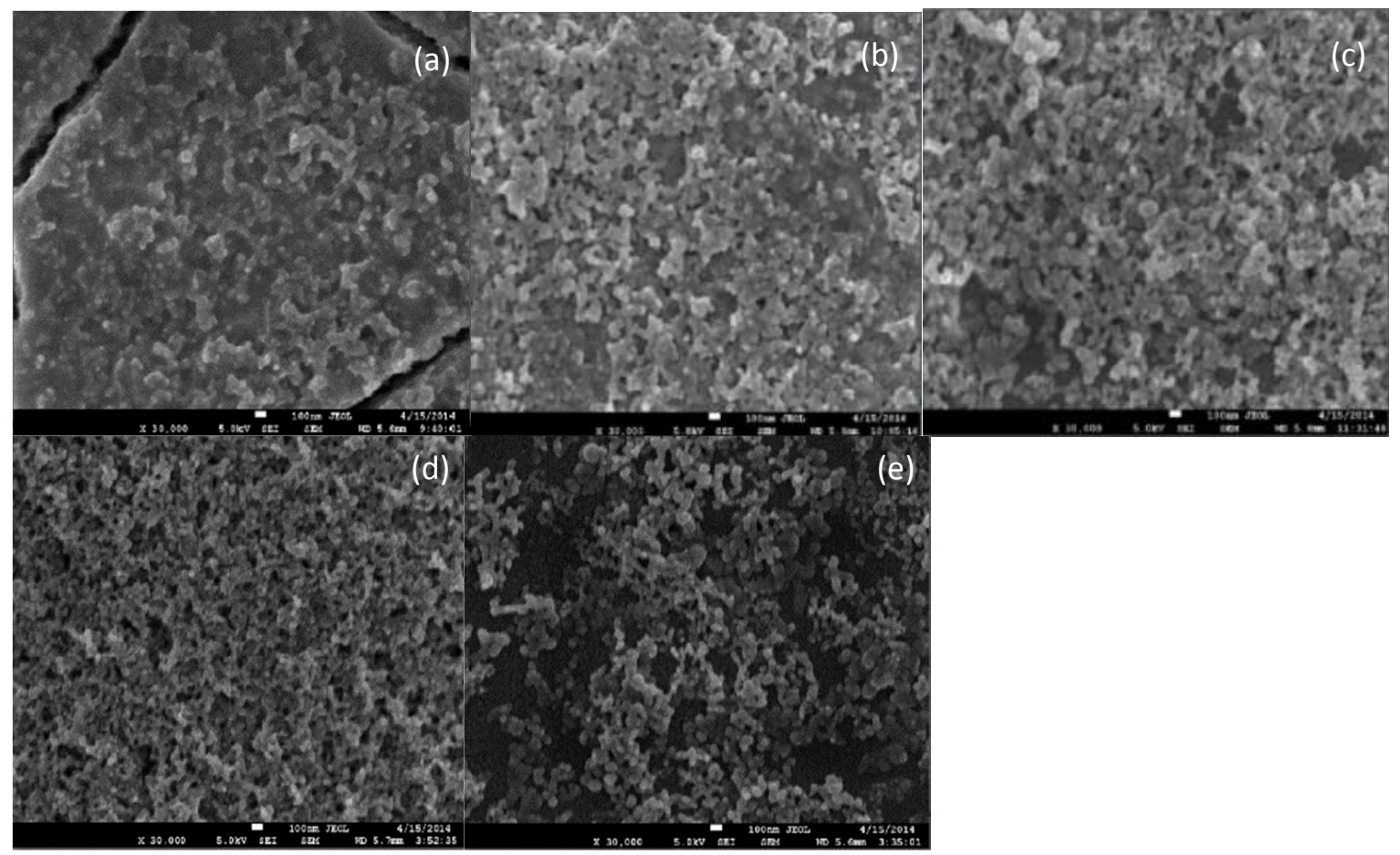

Figure 1 FESEM micrographs of FTO films obtained for different deposition temperature at (a) $250^{\circ} \mathrm{C}$, (b) $300^{\circ} \mathrm{C}$, (c) $350^{\circ} \mathrm{C}$, (d) $400^{\circ} \mathrm{C}$ and (e) $450^{\circ} \mathrm{C}$ respectively.

Optical Properties of FTO Thin Film. The transmisttance of FTO thin films with different deposition temperature were examined by using the UV-Vis specrometer using wavelength ranging from $300 \mathrm{~nm}$ to $800 \mathrm{~nm}$ as shown in Figure 2. The transmittance of FTO thin films reached over $80 \%$ as stated in Premalal paper [10]. The transmittance of FTO thin films increases as the temperature becomes higher. But as the temperature reaches $400^{\circ} \mathrm{C}$, it becomes lower. However, it increased back again when the tempearature increases to $450^{\circ} \mathrm{C}$. The transmittance with $91.3 \%$ was the highest value for the temperature of $350^{\circ} \mathrm{C}$ whereas lowest value goes to temperature of $400^{\circ} \mathrm{C}$ with $86.9 \%$. The reason for the temperature of $400^{\circ} \mathrm{C}$ to exhibit the lowest value of transmittance is because the arrangement of its crystallite particles is fully densely packed resulting to most of the visible light being unable to pass through. The variation of transmittance due to the optical scattering by surface morphology and grain boundaries of FTO in this study [11].

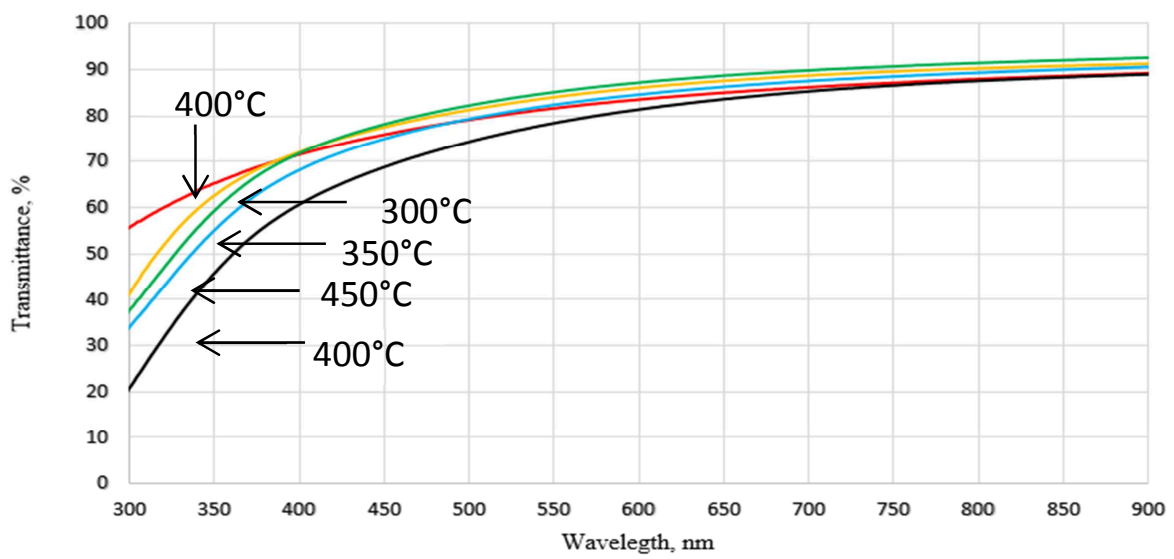

Figure 2 Variation of transmittance with wavelength for spray deposited FTO thin films at different deposition temperature. 
Electrical properties of FTO Thin Film. The measurement of electrical properties of FTO thin film at different deposition temperatures were measured and recorded by using the two point probe. In order to obtain the resistance of FTO thin film, slope of I-V had been measured. The gradient of the graph can be calculated using the following formula:

$$
\begin{aligned}
& \text { Gradient of the } \mathrm{I}-\mathrm{V} \text { curve }=\frac{\mathrm{I}}{\mathrm{V}} \\
& \text { Thus, resistance, } \mathrm{R}=\frac{\mathrm{V}}{\mathrm{I}}
\end{aligned}
$$

Refer to Table 1, the resistance of FTO thin film decreases as the deposition temperature increases. In other words, the resistance of thin films is inversely proportional to its deposition because the fluorine concentration is increase but when the temperature more than $400^{\circ} \mathrm{C}$, the concentration limit of fluorine is dropped [11]. Thus the fluorine concentration plays important role as electrons carrier.The parameter of this study was summarized in the Table 1.

Table 1 The summary of the study at various deposition temperature including thickness, $\mathrm{t}(\mathrm{nm})$, sheet resistance, $R_{\text {sh }}\left(\Omega / \mathrm{m}^{2}\right)$, optical transmittance, $T(\%)$ and resistivity, $\rho(\Omega . \mathrm{cm})$.

\begin{tabular}{|c|c|c|c|c|}
\hline $\begin{array}{c}\text { Temperature, } \\
{ }^{\circ} \mathrm{C}\end{array}$ & $\begin{array}{c}\text { Thickness, } \mathrm{t} \\
(\mathrm{nm})\end{array}$ & $\begin{array}{c}\text { Transmittance, } \mathrm{T} \\
(\%)\end{array}$ & $\begin{array}{c}\text { Resistivity, } \rho\left(\times 10^{6} \Omega\right. \\
\mathrm{cm})\end{array}$ & $\begin{array}{c}\text { Sheet resistance, } \mathrm{R}_{\text {sh }} \\
\left(\Omega / \mathrm{m}^{2}\right)\end{array}$ \\
\hline 250 & 77.59 & 89.2 & 1704.3750 & $2.20 \mathrm{E}+14$ \\
\hline 300 & 87.43 & 90.2 & 11.1375 & $1.27 \mathrm{E}+12$ \\
\hline 350 & 123.93 & 91.3 & 0.6878 & $5.55 \mathrm{E}+10$ \\
\hline 400 & 247.22 & 86.9 & 0.5694 & $2.30 \mathrm{E}+10$ \\
\hline 450 & 101.28 & 89.2 & 12.3881 & $1.22 \mathrm{E}+12$ \\
\hline
\end{tabular}

\section{Conclusion}

Polycrystalline FTO thin films were achieved by spray pyrolysis technique and manipulate the deposition temperature in the range of $250^{\circ} \mathrm{C}$ to $450^{\circ} \mathrm{C}$ onto glass substrates. The precursor used was $\mathrm{SnCl}_{4} .5 \mathrm{H}_{2} \mathrm{O}$ and $\mathrm{NH}_{4} \mathrm{~F}$ dissolved in distilled water. The effects of deposition temperature on the surface morphology, optical properties and electrical properties of FTO thin films were investigated. The arrangement of crystallite particles becomes more densely packed at temperature around $350^{\circ} \mathrm{C}$ to $400^{\circ} \mathrm{C}$. The thickness of FTO thin film increased from $250^{\circ} \mathrm{C}$ to $400^{\circ} \mathrm{C}$ while the thickness decreases at the temperature of $450^{\circ} \mathrm{C}$. The FTO film deposited on $400^{\circ} \mathrm{C}$ revealed the minimum resistivity of about $0.57 \times 10^{6} \Omega \mathrm{cm}$ and maximum transmittance of $89.4 \%$ at $350^{\circ} \mathrm{C}$. FTO thin film produces with high conductivity and transparency are likely to be useful in energy collecting application.

\section{Acknowledgements}

The author would like to acknowledge colleagues at Microelectronic and Nanotechnology Shamsuddin Research Centre (MiNT-SRC), Universiti Tun Hussein Onn Malaysia for providing technical and moral support. The authors are grateful to the Fundamental Research Grant Scheme (FRGS) Vot 1215 for research funding support. 


\section{References}

[1] S.J Ikhmayies, R.N. Ahmad-Bitar. Effect of Processing on the Electrical Properties of SprayDeposited $\mathrm{SnO}_{2}$ :F Thin Films. Am. J. Applied Sci. 5 (2008) 672-677.

[2] A. Chitra, R. B. Matathe, G.M. Takwale and G.V. Bhide. Structural properties of $\mathrm{SnO}_{2}$ : F films deposited by spray pyrolysis technique. Thin Solid Films. 164 (1998) 261-264.

[3] V.Bilgin, I.Akyuz, E. Ketenci, S. Kose, F. Atay, Electrical, structural and surface properties of fluorine doped tin oxide films, Applied Surface Science. 256 (2010) 6585-6591.

[4] K. Subba Ramaiah, V. Sundara Raja, Structural and electrical properties of fluorine doped tin oxide films prepared by spray-pyrolysis technique, Applied Surface Science, 253 (2006) 14511458.

[5] D. Tatar, G. Turgut and B. Duzcun, Effect of substrate temperature on the crystal growth orientation and some physical properties of $\mathrm{SnO}_{2}: \mathrm{F}$ thin films deposited by spray pyrolysis technique, Rom. Journ, Phys. (2013) 143-158.

[6] A.A. Yadav, E.U. Masumdar, A.V. Moholkar, K.Y. Rajpure, C.H. Bhosale, Effect of quantity of spraying solution on the properties of spray deposited fluorine doped tin oxide thin films, Physica B: Condensed Matter. 404 (2009) 1874-1877.

[7] H. Cachet, J. Bruneaux, G. Folcher, C. Levy-Clement, C. Vard, M. N. Spallart, Films and powder of fluorine doped tin oxide, in: T. Nakajima, H. Groult (Eds.), Fluorinated materials for energy conversion, Elsevier Ltd., 2005, pp. 507-534.

[8] A.V. Moholkar, S.M. Pawar, K.Y. Rajpure, C. H. Bhosale, Effect of concentration of $\mathrm{SnCl}_{4}$ on sprayed fluorine doped tin oxide thin films, Journal of Alloys and Compounds. 455 (2008) 440-446. [9] E. Elangovan, K. Ramamurthi, Studies on micro-structural and electrical properties of spraydeposited fluorine-doped tin oxide thin films from low cost precursor, Thin Solid Films. 476 (2004) 231-236.

[10] E. Premalal, N. Dematage, S. Kaneko, A. Konno, Preparation of high quality spray-deposited fluorine-doped tin oxide thin films using dilute di(n-butyl)tin(iv) diacetate precursor solutions, Thin Solid Films. 520 (2012) 6813-6817.

[11] L. Chin-Ching, C. Mei-Ching, C. Yu-Wei, Temperature dependence of fluorine-doped tin oxide films produced by ultrasonic spray pyrolysis, Thin Solid Films. 518 (2009) 1241-1244. 